\title{
Obtaining a new kind of organic fertilizer on the basis of low-grade phosphorite of Central Kyzylkum
}

\author{
Pridobivanje nove vrste organskega gnojila na osnovi \\ nizkoprocentnega fosforita iz osrednjega Kizilkuma v Uzbekistanu
}

\author{
Nodirjon Abdihakimovich Doniyarov*, Ilkhom Ahrorovich Tagayev \\ ${ }^{1}$ Navoi State Mining Institute, Navoi, Uzbekistan \\ * intelekt_16@mail.ru
}

\begin{abstract}
The paper presents the results of processing low-grade phosphorites by microorganisms of activated sludge from the biochemical purification production unit of JSC "Navoiazot". The obtained results on the leaching of rare and rare-earth elements into the liquid phase make it possible to separate them and thus enrich the phosphorites. Other options are the gravitational separation of the crushed calcite particles. In addition to this, there is a real possibility of creating complex organomineral fertilisers.
\end{abstract}

Key words: activated sludge, organomineral fertilisers, phosphorite flour, fluorapatite, francolite

\section{Povzetek}

V članku so predstavljeni rezultati obdelave nizkoprocentnih fosforitov z mikroorganizme vsebujočim aktivnim blatom iz proizvodne enote za biokemijsko prečiščevanje Delniške družbe "Navoiazot". Rezultati izluževanja redkih in redkozemeljskih prvin v tekočo fazo kažejo, da jih je mogoče ločevati in tako fosforite bogatiti. Nadaljnja možnost je težnostno ločevanje drobcev kalcita. Razen tega se kaže obetavna tudi možnost pridobivanja kompleksnih organskomineralnih gnojil.

Ključne besedes: aktivno blato, organskomineralna gnojila, fosforitna moka, fluorapatit, francolit 


\section{Introduction}

Uzbekistan, being an agro-industrial country, occupies 3.73 million hectares of irrigated arable land. It produces $97 \%$ of the country's agricultural output.

It turns out that we have only $39.8 \mathrm{~kg}$ of $\mathrm{P}_{2} \mathrm{O}_{5}$ per hectare of irrigated arable land, while it is necessary to insert for growing grain crops $100-120 \mathrm{~kg} / \mathrm{ha} \mathrm{P}_{2} \mathrm{O}_{5}$, cotton $145-165 \mathrm{~kg} / \mathrm{ha}$ $\mathrm{P}_{2} \mathrm{O}_{5}$, vegetable crops $100-110 \mathrm{~kg} / \mathrm{ha} \mathrm{P}_{2} \mathrm{O}_{5}$, rice $140-145 \mathrm{~kg} / \mathrm{ha} \mathrm{P}_{2} \mathrm{O}_{5}$ and maize for grain $120-140 \mathrm{~kg} / \mathrm{ha} \mathrm{P}_{2} \mathrm{O}_{5}$. This indicates that our agricultural production is experiencing a large deficit in phosphorus fertilisers. Deficiency of phosphorus fertilisers is further aggravated by the fact that a large number of nutrient components are removed from the soil with the crop. It is known that one ton of raw cotton takes out $45 \mathrm{~kg}$ of nitrogen, $15 \mathrm{~kg}$ of $\mathrm{P}_{2} \mathrm{O}_{5}$ and $45 \mathrm{~kg}$ of $\mathrm{K}_{2} \mathrm{O}$ from the soil annually. One ton of wheat takes out $35 \mathrm{~kg}$ of nitrogen, $10 \mathrm{~kg}$ of $\mathrm{P}_{2} \mathrm{O}_{5}$ and $24 \mathrm{~kg}$ of $\mathrm{K}_{2} \mathrm{O}$ from the soil every year. With a gross harvest of 3 million tons of raw cotton and 6.1 million tons of wheat, only 348,500 tons of nitrogen, 106,000 tons of phosphorus and 281,400 tons of potassium are lost annually from these two crops. However, other cultures also carry a large amount of nutrients out of the soil. It should be noted that the production of phosphorus-containing fertilisers in the Republic is limited by the quality of the phosphorite of the Central Kyzylkum field. It is a phosphorus-poor raw material, which also contains a large amount of undesirable impurities, in particular, carbonates and chlorine. Such a raw material is not suitable for obtaining highly concentrated phosphorus-containing fertilisers; in other words, it is not suitable for nitric, sulphuric and hydrochloric acid processing into concentrated phosphorus-containing fertilisers. A large amount of acid will be spent not on decomposition of fluorapatite but on interaction with calcium carbonate, giving large-scale waste products such as nitrate, sulphate and calcium chloride. Acid processing of such highly carbonised raw materials is accompanied by abundant foaming, which largely violates the whole technological process and reduces the productivity of equipment. To get a high-quality phosphorus fertiliser from such raw materials, they must be pre-enriched.

Therefore, the Kyzylkum Phosphorite Plant (KFP) carried out multi-stage enrichment: crushing, dry enrichment to obtain ordinary phosphorite flour, washing away from chlorine and roasting to remove $\mathrm{CO}_{2}$. At present, KFP produces three types of phosphate raw materials using the method of thermal treatment at a temperature of $1200^{\circ} \mathrm{C}$ : washed burned concentrate $\left(\mathrm{P}_{2} \mathrm{O}_{5}-27-29 \%, \mathrm{C} 1<0.04 \%\right)$ in the volume of 400 thousand tons per year, washed dried concentrate $\left(\mathrm{P}_{2} \mathrm{O}_{5}-18-19 \%\right)$ in the amount of 200 thousand tons per year and ordinary phosphorite flour $\left(\mathrm{P}_{2} \mathrm{O}_{5}-16-18 \%\right)$ in the amount of 200 thousand tons per year. The availability of phosphorus fertilisers for the Republic's agriculture is only $29-30 \%$. The situation is aggravated also by the fact that the coefficient of phosphorus utilisation by plants from phosphorus fertilisers introduced into the soil is extremely low and does not exceed $20 \%$. The rest of the phosphorus is fixated on the soil and shows a slight effect already in the after-effect [1].

The vast majority of ores in their natural form do not meet the requirements of either $\mathrm{P}_{2} \mathrm{O}_{5}$ or the amount of harmful impurities. Therefore, one more important stage - enrichment - is included in the general scheme for processing phosphorite ores. Its essence consists of concentrating by various mechanical methods of a useful mineral and removing harmful and ballast impurities in the tail (tails). Enrichment is based on the features of the structure and the difference in the properties of ore minerals. The methods used in the enrichment of phosphorites are the same as those used in metallurgy. A large number of methods are given, among which are used the following: ore disintegration, enrichment by size, gravity separation, flotation, roasting and selective removal of carbonates by different reagents [2]. The German company "KHD Humboldt Vedag AG" built and commissioned a factory for dry enrichment near the Khouribga deposit (Morocco). The regularities of flotation behaviour of minerals served as the basis for selective flotation of carbonate phosphorites of Karatau [3]. The technological scheme with the use of flotation enrichment methods is given in Cheryatu [4], 
where the presence of a phosphate ion in the pulp enhances the difference in the properties of the dolomite and phosphate surfaces, providing dolomite flotation with fatty acids [5,6]. In an acidic environment, the collector is in a molecular form and to increase its dispersity. It is proposed to feed the flotation with fatty acids in combination with alkyl-acrylic sulphates. For example, after the firing process, the content of $\mathrm{P}_{2} \mathrm{O}_{5}$ in the calcined concentrate is $27 \pm 1 \%[7,8]$. In the scientific literature, numerous methods have been suggested for enriching poor phosphorite ore [11] with various gases (oxides $\mathrm{SO}_{2}$ [9], $\mathrm{NO}$ and $\mathrm{NO}_{2}$ [10]) and acids ( $\mathrm{HCl}[11,12]$, $\mathrm{H}_{2} \mathrm{SO}_{4}[13,14], \mathrm{H}_{3} \mathrm{PO}_{4}[15,16]$ and $\left.\mathrm{HNO}_{3}[17]\right)$.

The new method of biotechnological treatment that we applied is based on the ability of certain types of microorganisms under certain conditions to use pollutants as their food. A lot of microorganisms that make up the active sludge of the biological treatment plant, being in the waste liquid, absorb pollutants into the cell where they undergo the biochemical transformations under the influence of enzymes. In this case, organic and some types of inorganic pollutants are used by the bacterial cell in two ways:

1. Biological oxidation in the presence of oxygen into harmless products of carbon dioxide and water:

Organic matter $+\mathrm{O}_{2}$ (in the presence of enzymes) $=>\mathrm{CO}_{2}+\mathrm{H}_{2} \mathrm{O}+\mathrm{Q}$.

2. The energy released in this case is used by the cell to support its vital activities (movement, breathing, reproduction, etc.).
Synthesis of a new cell (multiplication): Organic substance $+\mathrm{N}+\mathrm{P}+\mathrm{Q}$ (in the presence of enzymes) $=>$ new cell [18].

The aim of the studies was to study the possibility of microorganisms of active silt for their growth and development to use carbon carbonates in the composition of calcite.

\section{Object and methods of research}

The object of the study was the phosphorite ore of the Jeroy-Sardarinsky deposit with chemical composition given in Table 1.

In connection with the foregoing, there have been conducted laboratory studies on the leaching of various elements from low-grade phosphorites of the Jeroy-Sardarinsky deposit using aerobic species of neutrophil microorganisms of the active sludge of the biochemical purification station of JSC Navoiazot.

The microflora of activated sludge from the biochemical purification plant in the form of a liquid phase (L) was mixed with phosphorite ( $\mathrm{S}$ - solid) in a ratio of L:S (liquid:solid) $=4: 1$. The experiments were carried out in several versions in reactors simulating aerotanks using water, activated sludge, activated sludge with nitrogen feed and compressed air supply with continuous mixing.

After bacterial leaching for 14 days, samples of the liquid and solid phases were sent to State Unitary Enterprise "Uzgeorangmetliti" for $\mathrm{X}$-ray fluorescence energy-dispersive spectral

Table 1: Chemical composition of phosphorites of Central Kyzylkum.

\begin{tabular}{cccccc} 
No & $\begin{array}{c}\text { Names of } \\
\text { compounds }\end{array}$ & $\begin{array}{c}\text { Content of } \\
\text { elements, \% }\end{array}$ & No & $\begin{array}{c}\text { Names of } \\
\text { compounds }\end{array}$ & $\begin{array}{c}\text { Content of } \\
\text { elements, \% }\end{array}$ \\
\hline 1 & $\mathrm{P}_{2} \mathrm{O}_{5}$ & $8.0-12.0$ & 8 & $\mathrm{CO}_{2}$ & $8-15$ \\
\hline 2 & $\mathrm{Al}_{2} \mathrm{O}_{3}$ & $1.5-3.0$ & 9 & Fluorine & $1.8-3.2$ \\
\hline 3 & $\mathrm{SiO}_{2}$ & $6.0-8.0$ & 10 & $\mathrm{SO}_{3}$ & $2.5-3.5$ \\
\hline 4 & $\mathrm{CaO}$ & $42-48.1$ & 11 & $\mathrm{U}$ & $0.003-0.008$ \\
\hline 5 & $\mathrm{MgO}$ & $2.5-3.5$ & 12 & $\begin{array}{c}\text { The amount of rare } \\
\text { earth elements }\end{array}$ & $0.04-0.089$ \\
\hline 6 & $\mathrm{Fe}_{2} \mathrm{O}_{3}$ & $0.6-0.8$ & 13 & Ho & 10.0 \\
\hline 7 & $\mathrm{SO}_{3}$ & $2.8-3.0$ & 14 & Insoluble residue & $8.0-8.2$ \\
\hline
\end{tabular}


analysis performed using the BRA-135F instrument. The universal X-ray fluorescence energy dispersive spectrometer BRA-135F allows to simultaneously determine up to two dozens of chemical elements in a time not exceeding 300 seconds in a wide range of concentrations from hundreds of ppb. BRA-135F analyses the samples in solid, powdery, liquid states, as well as those deposited on the surface or on filters. In order to determine the shape of phosphorite grains and calcite crystals, a conventional light microscope "Celestron" was used, where at an increase of 200 times, the production of not only conventional but also stereoscopic images were achieved, changing the angle of illumination (illumination was carried out from the surface part of the sample).

\section{Results and discussion}

Active sludge is a complex substance that participates in the sewage treatment process and is an amphoteric colloidal system. Biofilm is a collection of microorganisms located on the surface of sewage. The composition of activated sludge and biofilm directly depends on the chemical composition, temperature, $\mathrm{pH}$ and other characteristics of sewage from the sewerage of country houses and other residential objects.

\section{Organic substances of activated sludge}

Dry silt matter in septic tanks without pumping (autonomous sewage treatment plants) contains $70-90 \%$ of organic substances in living organisms. They are represented in 12 main types of protozoa and microorganisms. The main activators of the sludge are bacteria: in $1 \mathrm{~m}^{3}$, the number of bacteria is up to $2^{\prime} 10^{14}$. They form clusters, surrounded by mucus. Nitrosomonas, nitrobacter, bacillus and some other microorganisms live in the biocenosis of the sludge. They are absorbed by flagellar, sarcodic, sucking and ciliated infusoria, resulting in clarification and sedimentation of the silt. The listed microorganisms, in turn, feed on worms (rotifers, eolosomes). Active sludge and biofilm contain $10-30 \%$ of inorganic substances such as water, a substrate (solid residues to which microorganisms are attached) and an inorgan- ic suspension. The processes of biological oxidation can take place only in the presence of water and a significant amount of oxygen, and reproduction can take place only with the participation of nitrogen and phosphorus. Active silt contains also trace elements (manganese, sulphur, cobalt, iron, etc.). The ecosystem of activated sludge is artificially created and depends on various factors of its environment. Therefore, the species inhabiting it, in terms of abundance and species diversity, differ significantly from those that exist in the natural environment. Those microorganisms that began to dominate in numbers among the rest, due to natural selection, associated with the peculiarities of the composition and properties of the nutrient medium of the aerotank, created by wastewater, have high adaptive properties, due to the conditions of their selective selection. In this biomass, there are colonies of bacteria and microorganisms that ensure the release of carbon, biogenic and other elements from waste water [18].

This process is carried out with the aerobic action of activated silt on phosphorites for 14 days. On the 4th-5th day, microscopic examination of phosphorites revealed a change in the morphological structure of phosphorite grains, where they turned from irregularly angular to round and spherical structure, with a parallel decrease in grain size. In the aerobic decomposition of effluents, two basic microbiological processes occur: oxidation of organic carbon and nitrification with the participation of filamentous, flocculating microorganisms and bacterial nitrifiers. Flocculating bacteria are responsible for the oxidation of organic compounds. These include microorganisms of the genera Actinomyces, Alcaligenes, Bacillus, Cellulomonas, Desulfotomaculum, Flavobacterium, Mycobacterium, Nocardia, Pseudomonas, Sarcina and others. The most numerous bacteria (up to 80 percent of the whole complex of microorganisms) are microorganisms of the genus Pseudomonas, capable of oxidising alcohols, paraffins, fatty acids, carbohydrates and aromatic hydrocarbons. It is known that species of the genus Pseudomonas are able to oxidise also cyanides. Carbon-oxidising filamentous microorganisms are represented by the genera Spherotilus, Beggiatoa and Thiotrix. 
At the same time, these microorganisms are the main cause of poor sedimentation of sludge in the settler and the formation of a stable foam in the device. During purification of sinks with a high carbohydrate content and nitrogen deficiency, there is sometimes an intensive development of heterofermentative lactic acid bacteria of the genus Leuconostoc, which form a powerful dextran capsule, which hinders sedimentation of the sludge in the settler. The most active nitrification processes occur after the oxidation of the organic component. In sewage with sulphur content, sulphate reductors, thionic and sulphur bacteria develop. Thionic microorganisms develop under the condition that the reduced sulphur compounds are contained in the effluents.

In the absence of organic compounds in the composition of phosphorites, many species of microorganisms die. However, the characteristics of heterotrophic microorganisms are that they can adapt to any environmental conditions and, with a lack of organic compounds, are able to switch to inorganic compounds and oxidise them. Extracellular enzymes in active silt contain proteases, hydrolases, cellulases and peroxidases. Extracellular enzymes catalyze the oxidation of substrates with the participation of hydrogen peroxide and catalase, decomposing $\mathrm{H}_{2} \mathrm{O}_{2}$.

Phosphorites of the Kyzylkum are composed mainly of phosphatised faunal residues, bound with fine-grained calcite cement [19]. Among phosphatised remains of fauna, foraminifera prevails with sizes of shells from 0.04 to $0.5 \mathrm{~mm}$. Isotropic and weakly crystallised phosphate with point inclusions of calcite fill the internal cavities of their shells. Relic calcite, preserved from phosphate substitution, sometimes also forms a shell and internal septa shells. In the scientific and technical literature, such a calcite, which is located inside the phosphate formations, is called the "endocalcite", and the cement composing the rock is called the "exocalcite". The third form of calcium carbonate is found in the form of a phosphate mineral isomorphically entering the crystal lattice.

The subordinate role is played by the phosphatised remains of other groups of organisms: valves and cores of pelecites, gastropod shells up to $5 \mathrm{~mm}$ in size and up to $5-10 \%$ in plac- es, elongated cone-shaped pteropods up to 4-5 $\mathrm{mm}$ in length and up to $1.5 \mathrm{~mm}$ in diameter, needles of sea urchins, fish scales, etc. Cementation is often unstable; many phosphorites easily disintegrate under mechanical action, especially after soaking in water. Among organic residues, a small amount of primary phosphate material is present - teeth of sharks, vertebrae and small (several millimetres) fragments of bones of marine animals. The cement of phosphorites is fine-grained calcite with an admixture of clay and phosphate-clay material. In the terminal part of the second layer, the cement is a strong crystalline; it is represented by calcite and gypsum and sometimes with a siliceous component. The results of mineralogical study of granular phosphorite ores indicate a monotony of their composition. The main phosphate minerals - francolite (fluorocarbonatepatite) and calcite - compose $80-90 \%$ of the ore. Francolite contains on average about $42.1 \% \mathrm{P}_{2} \mathrm{O}_{5}$, $55.4 \% \mathrm{CaO}, 1.2 \% \mathrm{~F}, 2.3 \% \mathrm{Cl}$ and $0.6 \% \mathrm{H}_{2} \mathrm{O}$; the sum of rare elements (TR) reaches $0.03 \%$. The ore of the deposit has the following average mineral composition (weight, \%): francolite 56.0 , calcite -26.5 , quartz $-7.5-8.0$, hydromica minerals and feldspars - 4.0-4.5, gypsum - 3.5, goethite -1.0 , zeolite $<1.0$ and organic matter about $0.5[21,22]$.

It should be noted that the distinctive feature of the Kyzylkum phosphorites is their high degree of carbonate content; the concentration of $\mathrm{CO}_{2}$ in some formations reaches $27 \%$ or more.

The obtained results confirmed the assumptions about bacterial leaching of various elements, in particular, strontium, thorium and uranium into the solution. In the variant with active silt, the amount of strontium and thorium leached into the solution was respectively 21.2 and $1.09 \mathrm{mg} / \mathrm{l}$ (adequately).

Spectral analysis of samples (spectral analyzes were conducted using X-ray fluorescent energy-dispersive spectrometer BRA-135F) treated with active silt showed that not only radioactive metals but also rare-earth metals were released into the liquid phase. In the solid phase, the amount of radioactive and rare-earth metals varied within different limits, proceeding from partial dissolution and isolation into the liquid phase. The greatest amount of uranium $(7.97 \mathrm{mg} / \mathrm{l})$ was leached in the version with the 
Table 2: Distribution of alkaline earth and radioactive metals in solid and liquid phases ( $\mathrm{mg} / \mathrm{l})$.

\begin{tabular}{|c|c|c|c|c|c|c|c|c|c|c|c|c|}
\hline \multirow{2}{*}{ No } & \multirow{2}{*}{ Variants } & \multicolumn{8}{|c|}{ Solid phase } & \multicolumn{3}{|c|}{ Liquid phase } \\
\hline & & Mo & $\mathbf{N i}$ & $\mathrm{Cu}$ & Zn & As & $\mathrm{Sr}$ & Th & $\mathbf{U}$ & $\mathrm{Sr}$ & Th & $\mathbf{U}$ \\
\hline 1 & Initial & 0.000193 & -0.00521 & 0.0026 & 0.01228 & 0.000918 & 510.521 & 3.2480 & 1.9065 & - & - & - \\
\hline 2 & $\begin{array}{l}\text { Initial } \\
+\mathrm{H}_{2} \mathrm{O}\end{array}$ & 0.000247 & -0.00385 & -0.0008 & 0.01781 & 0.001421 & 683.448 & 7.2064 & 14.325 & 13.04 & 0.547 & 4.452 \\
\hline 3 & $\begin{array}{c}\text { Alkaline } \\
\text { initial } \\
+\mathrm{H}_{2} \mathrm{O}\end{array}$ & 0.000241 & -0.00502 & -0.0012 & 0.01444 & 0.001547 & 544.353 & 3.5165 & 0.5553 & 21.20 & 1.090 & 5.964 \\
\hline 4 & $\begin{array}{c}\text { Alkaline } \\
\text { initial } \\
+\mathrm{O}_{2}++ \\
\text { urea }\end{array}$ & 0.000242 & -0.00533 & 0.0057 & 0.0143 & 0.001296 & 545.482 & 4.468 & 5.3095 & 11.63 & 0.421 & 7.971 \\
\hline
\end{tabular}

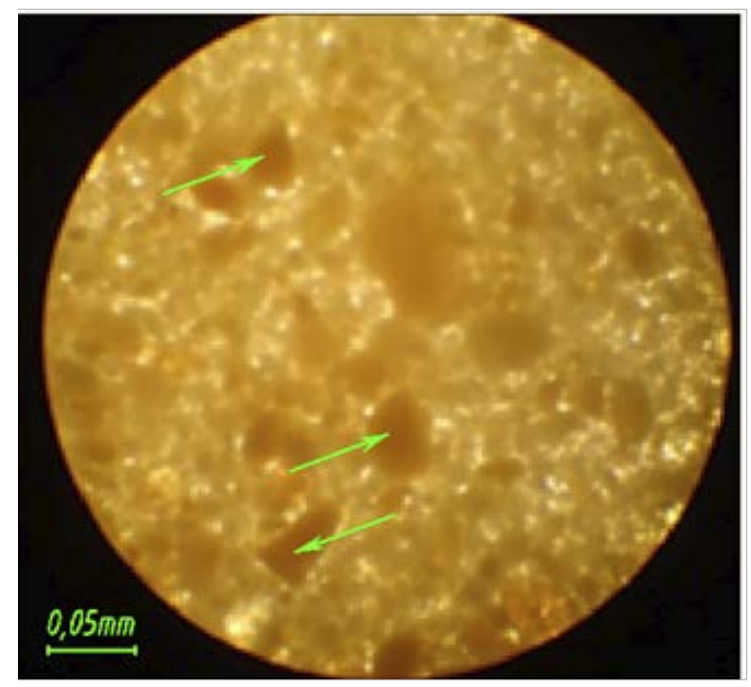

Figure 1: Control variant (the scale is $20 \times 10$ ).

use of activated sludge with air supply and using nitrogen fertilising in the form of urea. The behaviour of arsenic should be specially noted, which also underwent oxidation and passed into solution, especially in the third variant (Table 2).

The analysis under a microscope showed selective crushing of phosphorite ore. The obtained results show that, apparently, the microorganisms underwent destruction of the organic component of phosphorites, which is about $0.5 \%$. In addition, incidentally, as a source of phosphorus, they used phosphorite grains (francolite), which in microscopic photos decreased in size and acquired a spherical shape.

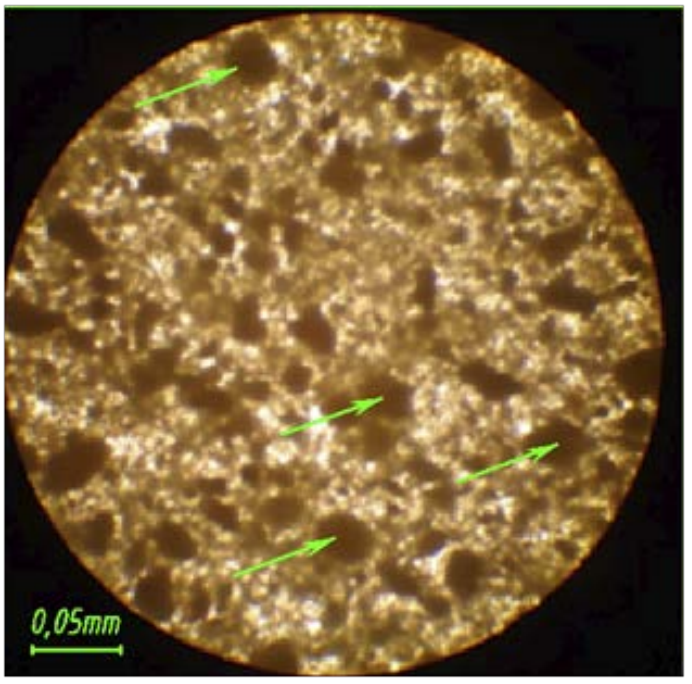

Figure 2: Treatment with activated sludge (the scale is $20 \times 10$ ).

In the control variant (Figure 1.), phosphorite grains are seen in fairly large sizes, up to 40-60 $\mathrm{mm}$ (shown by arrows). After processing the microflora of the activated sludge, the grains decreased in size to $20-35 \mathrm{~mm}$ (Figure 2), taking a round or spherical shape (indicated by arrows). When phosphorites with activated sludge were added to the nutrient mixture in the form of a nitrogen-containing fertiliser - carbamide and air aeration with the use of a compressor (Figure 3), the phosphorite grains further decreased in size to $5-15 \mathrm{~mm}$. Phosphorite grains are represented mainly by francolite, which has a complex chemical composition, in which the phosphorus content reaches up to $40 \%$ and the endocalcite up to 


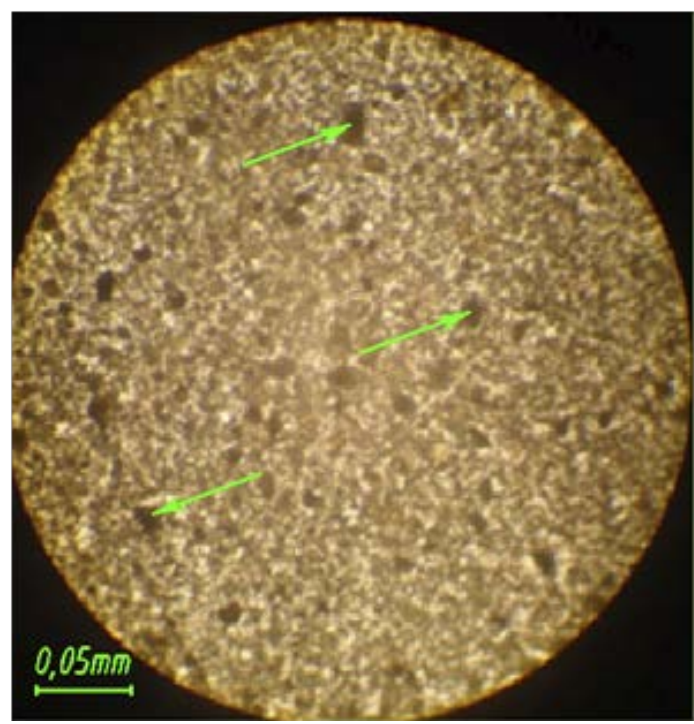

Figure 3: Treatment with activated sludge, carbamide and air (the scale is $20 \times 10$ ).

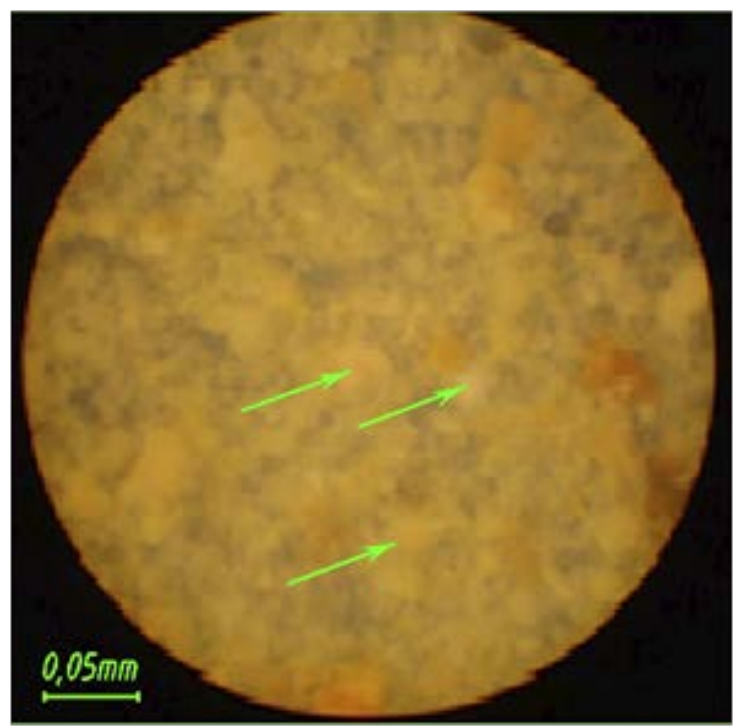

Figure 5: Treatment with activated sludge (the scale is $20 \times 10$ ).

55\%. Apparently, microorganisms used phosphorus and carbonate carbon in the composition of francolite for their growth and development, which led to a decrease in the grain size. Thus, the particles of phosphorite grains also underwent destruction and from an irregular angular form turned into round ones with a smaller size. Therefore, there is a real possibility of finding out phosphorites and an additional increase in the specific mass of $\mathrm{P}_{2} \mathrm{O}_{5}$ in the total fertiliser mass.

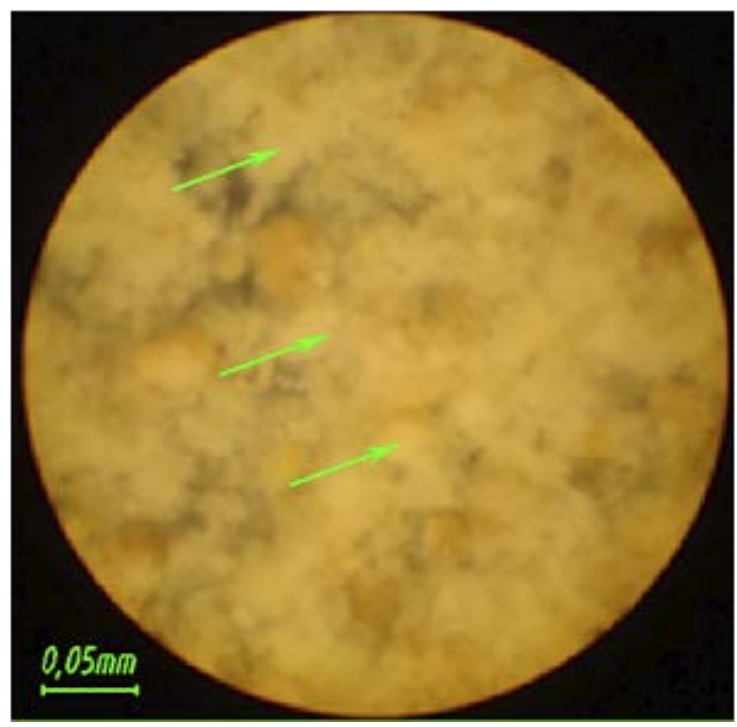

Figure 4: Control variant (the scale is $20 \times 10$ ).

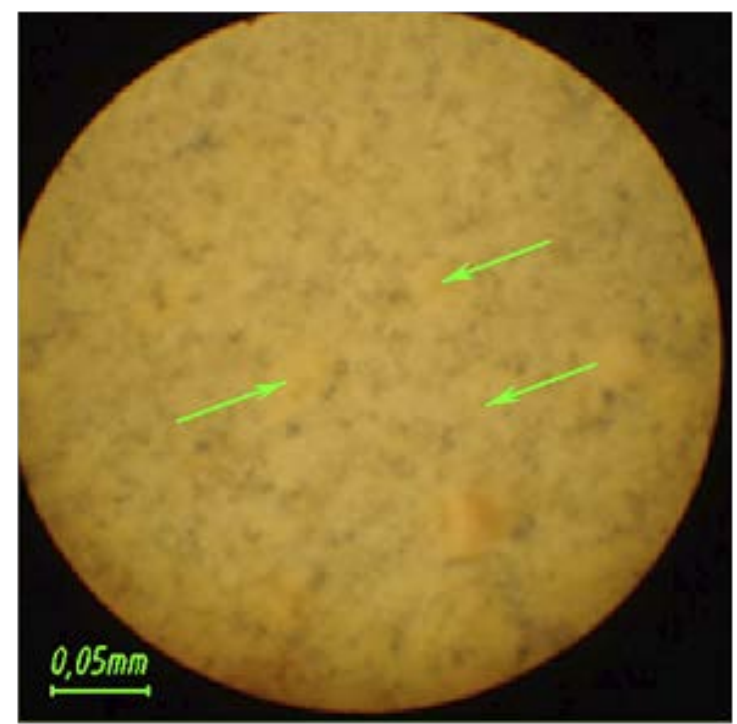

Figure 6: Treatment with activated sludge, carbamide and air (the scale is $20 \times 10$ ).

Analysis of stereoscopic microphotos (Figures 4-6) of calcite crystals showed the presence of calcite minerals in the form of large pieces of opaque colour (indicated by arrows) at the very beginning of the process in the control variant (Figure 4). The size of calcite grains varies from 40 to $80 \mu \mathrm{m}$. When calculating the microflora of the active silt (Figure 5), the calcite fragments of the mineral began to disintegrate, and when the microorganisms were fed with carbamide and supplied with oxygen of air (Figure 6), a complete decay of the calcite 
occurred, which looked as amorphous in which the calcite grains had a size of less than 1-2 mm. Phosphorite grains in the control variant had a larger size and irregular shape. Depending on the duration of bacterial treatment, the form of phosphorite grains began to decrease (Figures) and take a spherical shape. The main components of phosphorite ores (hardly soluble phosphates) were converted to hydro and dihydrogen phosphates, i.e. into more soluble and digestible forms.

Crystals of calcite began to disintegrate, and under stereoscopic observation using a microscope, they resembled the kind of powdered phosphorite grains (Figures. 4-6).

One of the options for enriching phosphorites, taking into account the grinding of calcite crystals and the change in the dimensions of phosphorite grains, is the possibility of their washing away from each other by a gravitational method. Fine calcites can be separated from larger phosphorite grains.

Among the chemical elements necessary for plants, 16 main biogenic microelements are distinguished: carbon, oxygen, hydrogen, nitrogen; ash elements - phosphorus, potassium, calcium, magnesium and sulphur and trace elements - boron, molybdenum, copper, zinc, cobalt, manganese and iron. The place of one element cannot be replenished by another, because each of them fulfils the specific physiological function assigned to them.

Trace elements are not accidental ingredients of tissues and fluids of living organisms but components of the naturally existing very ancient and complex physiological system involved in regulating the vital functions of organisms at all stages of development. Among the 15 vital elements, nine are cations - calcium $\left(\mathrm{Ca}^{2+}\right)$, sodium $\left(\mathrm{Na}^{+}\right)$, potassium $\left(\mathrm{K}^{+}\right)$, magnesium $\left(\mathrm{Mg}^{2+}\right)$, manganese $\left(\mathrm{Mn}^{2+}\right)$, zinc $\left(\mathrm{Zn}^{2+}\right)$, iron $\left(\mathrm{Fe}^{2+}\right)$, copper $\left(\mathrm{Cu}^{2+}\right)$ and cobalt $\left(\mathrm{Co}^{2+}\right)$. Six others are anions or are contained in complex anionic groups: chloride $\left(\mathrm{Cl}^{-}\right)$, iodide $\left(\mathrm{J}^{-}\right)$, phosphate $\left(\mathrm{PO}_{4}{ }^{3-}\right)$, sulphate $\left(\mathrm{SO}_{2}{ }^{4-}\right)$, molybdate $\left(\mathrm{MoO}_{2}{ }^{3-}\right)$ and selenite $\left(\mathrm{SeO}_{2}{ }^{3-}\right)$ [5]. Isolations of microorganisms contain a whole complex of organic compounds, consisting of vitamin-like substances and humic, abscisic, gibberellic and other acids in the form of growth stimulators and plant development. Thus, along with the enrichment of low- grade phosphorites with active silt microorganisms and their excreta, they will be enriched by additional stimulating compounds and microelements stimulating growth and development of plants [24].

\section{Conclusion}

Treatment of low-grade phosphorites with microflora of activated silt led to a change in the structure of phosphorites, where the destruction of calcite mineral occurred and the phosphorite grains decreased in size and became round in shape, which indicates their partial dissolution and transfer to the form that is assimilated by plants.

Thus, the development of a biotechnological method for the destruction of low-grade phosphorites and their wastes is possible to create not only a fundamentally new technology but also an economically promising technology, since the active sludge is itself a source of macro- and microelements. Applying the methods of gravitational and flotation enrichment, it is possible to separate the maximum amount of calcite from phosphorite grains and supplement it with parallel extraction of radioactive, rare and rare-earth elements.

\section{References}

[1] Sultanov, B.E., Tursunova, Z.M., Namazov, S.S., Erkaev, A.U., Beglov, B.M. (2002): Influence of the concentration of a solution of calcium nitrate on the degree of washing of a concentrate of phosphorites of the Central Kyzylkum. Uzbek chemical journal, 4, pp. 10-13.

[2] Shilaev, V.P. Fundamentals of mineral processing. (1986): Moscow: Nedra, pp. 247-255.

[3] Nabiulina, Y.N., Wasserman, B.I., Panova, N.S. (1977): Reduction of material entrainment during firing" Tr. GIGHS, pp. 92-95.

[4] Cheryatu, Y.S. (1988): Reagents for the flotation of magnesium-containing phosphorite ores. Dep. In ONIITEHIM, LGI, p. 6, 1988, 17.10.83.

[5] Malinskaya, I.S. (1968): Searching for anion collectors for flotation of phosphorites and studying the features of their action" thesis for Cand. tech. Sci., Moscow, 1968; pp. 85-103. 
[6] Chepelevetskiy, M.L., Rubinov, S.S. (1987): Kinetics of the decomposition of minerals of the phosphate complex by acids". Tr. NIUIF, 137, pp. 10-73.

[7] Tolstov, E.A., Sytenkov, V.N., Kizimov, F.P. et al. (2002): Technological instruction for calcination of phosphorite ore from the roasting department. - Navoiy, NMMC, 2002, pp. 8-26.

[8] Wolfkovich, S.I. (1971): Enrichment of phosphorites of Karatau with sulfuric acid. Journal applied chemistry, 5, pp. 969-971.

[9] Orlov, E.A., Treushenko, N.N., Kopylev, B.A., Belchenko, G.V., Pchelintsev, V.N. et al. (1976): On the effect of temperature and composition of the gas and liquid phases on the process of enrichment of Karatau phosphorites with sulfur dioxide. Proceeding of Leningrad Technological Institute Named Lensovet, Leningrad City Council, Issue 5, pp. 137-143.

[10] Treuschenko, N.N., Kopylev, B.A., Belchenko, G.V., Tkacheva, V.A. (1976): Interaction of an aqueous suspension of carbonized phosphorite with nitrogen oxides. Proceeding of Leningrad Technological Institute Named Lensovet, Leningrad City Council, Issue 5, pp. 142-145.

[11] Hill, R.O. (1976): Treatment of materials containing phosphates: The patent of France G 01 in 25/01.-No. 2280584.-Pub. 27.02.76.

[12] Pozhin, M.E., Zhiltsova, D.F., Nikondrov, I.S. (1970): Method for purification of natural phosphorus-containing raw materials from impurities of magnesium compounds. The patent of the USSR Cl. From 05 to 9/00.-No. 283243.- Published on 18.12.70.

[13] Wengeler, W., Volstein, F., Hoffmann, E. (1977): Preparation of phosphate ores (for processing). The patent of Germany Cl. C 01 to 25/22.-No. 2531519.-Published on -20.01.77.

[14] Petersen A.W. (1973): Process of processing phosphate ore. US Patent. Cl. 423-320, С 01 в 25/16.-No. 3717702.-pub.20.02.73.
[15] Kamino, Y. et al. (1982): Preparation of EFC. The patent of Japan. MKI 01 to 25/222.-No. 55-174861.- pub. 23.06.82.

[16] Sardisco, J.B., Holcomb, D.E. et al. (1983): Enrichment of phosphate ponds. US Patent. 4393000 MKI S $01 \mathrm{~F}$ 1/00.-No. 338998.-publ.12.07.83.

[17] Rinberg, G.R. et al. (1980): Method for the enrichment of natural phosphates. The patent of the USSR From 05 In 11/04 to 735583. - publ. 25.05.80.

[18] Fedyaeva, O.A., Reshetnikova, E.V., Chachina, S.B. (2012): Investigations of the chemical composition of spent activated sludge of JSC Omsk Vodokanal. Proceedings of OmSTU. Department of Physical Chemistry, Russia, Omsk, p. 8.

[19] Netrouzov, A.I., Bonchosmolovskaya, E.A., Gorlenko, V.M. (2004): Ecology of microorganisms. Textbook for students, High schools, Moscow: Academy, pp. 2004-272.

[20] Tepexova, V.F., Burov, I.V. (1982): Physico-chemical properties and application of rare-earth metals. GOSINTY.

[21] Mintern, P.A. (1984): New research of rare earth metals. Collection of translations. Ed. EM Savitsky, 2, 212-220. "Mir" Publishing House.

[22] Smirnov, A.I. (1972): Material composition and conditions for the formation of basic types of phosphorites. Moscow, Nedra, p. 196.

[23] Skalny, A.V. (2004): Chemical elements in human physiology and ecology. Moscow. ONYX-21 century Mir, p. 218.

[24] Olikulov, F.A., Khamidov, O.Z., Tagayev, I.A. (2016): Development of a method for obtaining bioorganic fertilizers from domestic and industrial wastewater. Academy of Sciences of Uzbekistan. Institute of General and Inorganic Chemistry. Republican Scientific Conference of Young Scientists. Proceedings of the conference High-tech development in production. Tashkent, 2016, pp. 54-55. 